\title{
The Influence of Demographic Variables on Empirical Studies Concerning CIO Gender
}

\author{
Bjarne Erik Roscher ${ }^{1,2, *}$, Volker Nissen ${ }^{3}$ \\ ${ }^{1}$ Department of Business, Management and Economics, Universität von Lettland, Riga, Lettland \\ ${ }^{2}$ FOM Hochschule für Oekonomie \& Management, Standort Nürnberg, Essen, Deutschland \\ ${ }^{3}$ Fakultät für Wirtschaftswissenschaften und Medien, Fachgebiet Wirtschaftsinformatik für \\ Dienstleistungen, Technische Universität Ilmenau, Ilmenau, Deutschland \\ *Corresponding author: Bjarne Erik Roscher
}

\begin{abstract}
.
Companies are more and more dependent on information technology (IT) and the buzzword digitization is present everywhere. Some companies are inventing new business models based on disruptive innovation supported by information technology. Others adapt these business models as followers. All these new business processes and underlying information technology need to be managed, serviced, and supported by IT organizations to ensure business continuity. Traditionally heads of the IT department have been fully responsible for all aspects of IT usage in the company - including IT cost, IT governance, IT \& process planning and implementation and IT operation. This results in the fact that there is a need of more intensive Business-IT alignment to ensure the adequacy of the overall IT architecture in a company and ensure the economic value contribution of IT as a hole. In the last two decades researchers have investigated the area of CIO effectiveness by doing empirical research looking at IT roles/tasks, interaction and strategic importance of IT, personal background of CIOs. As a side effect some researchers have constructed and used demographic variables both as control and causal variables. This paper looks on the comparability and the source of such demographic data especially on the case of Gender information and highest academic title. It also discusses the question if survey results could be compared with representative datasets to evaluate validity of the sample and responses of empirical studies.
\end{abstract}

Keywords: Chief Information Officer (CIO), IT Organization, Gender, academic title, diversity

\section{Introduction}

Synnott defined 1981 the role of the chief information officer (CIO) as the "senior executive responsible for establishing corporate information policy, standards, and management control over all corporate information resources" (Synnott \& Gruber , 1981).

Many studies have shown that the role of a CIO is essential for an organization: 
A CIO can positively influence the company performance not only by fostering the IT efficiency, which means lowering cost and by this increase the profit, yet increase the IT effectivity through improved IT use (Durst , 2007).

Measures to drive IT efficiency are introducing tailored internal IT management systems (Schweda \& Schmidt, 2014) efficient IT service management [ITSM] frameworks (Marrone $\&$ Kolbe , 2011) and the right organizational setup (Hodgkinson , 1992). An efficient budgeting and controlling process which ensures that investments in technology deliver the planned results (Chan, Sabherwal \& Thatcher, 2006) is essential. Measures to improve IT effectivity are supporting business processes with appropriate information technology (Tallon , 2014).

But ultimately a CIOs main task is to ensure "Business-IT-Alignment" (BITA). This results in strategic information technology initiatives driving business performance (Peppard, 2010).

Searching the Internet about the Keywords "CIO", "Chief Information Officer", "Gender", "Woman" and "Diversity" result in many findings under the headline "Smashing the Glass Ceiling" . Several publications can be found regarding the share of women in CIO positions (Prabhakar et al. , 2018; Statista , 2018), about advantages of gender diversity in IT (Prabhakar et al. , 2018) and reasons why only a small share of women climb the IT career ladder to the highest possible position \}(Fitzsimmons, Callan \& Paulsen , 2014). Business Researchers like Harvey Nash \& KPMG and Deloite conduct global surveys frequently. The respondents are $\mathrm{CIO}$ and participant numbers are usually high $(\mathrm{N}>3000)$. One aspect of these surveys is the share of women in CIO positions.

Also, Scientific research approaches Chief Information Officers. Yet the research scope usually is limited depending on the definition of the research object, the industry or the regional scope. Another issue for scientific researchers is the availability of contact data and addresses. Not to forget the limited interest of business executives to answer surveys for scientific researchers as the results usually are not published in media which is freely or easily accessible for CIOs. And even if the data is freely available it sometimes takes month or years until the results are published by Journals or in monographs. By then the interest regarding the results is vanished in the fast-running business world.

\section{Research Question}

Are available data on CIO gender distribution - from scientific research, business research, company databases or statistics - a appropriate source for validating the representativeness of own survey based empirical research?

${ }^{1}$ The metaphor "Glass Ceiling" describes the invisible barrier which prevent minorities from rising to the highest level of hierarchy. In this context it describes the need for female candidates to work towards the highest hierarchy in IT which is the CIO position. 


\subsection{Methods}

The main Methods for this research have been literature review of scientific, business and internet sources and Database analysis.

\subsubsection{Literature Review}

For scientific literature, Science Direct and Researchgate.net have been searched for the keywords "CIO", Chief Information Officer" and only empirical quantitative research has been selected with a focus on effectivity and efficiency. After analysing the references for further relevant research a total of $n=11$ articles where identified. The Literature review ${ }^{2}$ was done in line with the Prisma-P Method (Moher et al. , 2015). The identified articles have been analysed for variables indicating Gender, Age and education/degree. Table 1 shows the appearance of variables in the papers.

Table 1: Overview of literature review regarding response rate of identified articles and inclusion of variables.

\begin{tabular}{|c|c|c|c|c|c|c|c|c|c|}
\hline First Autor & Year & 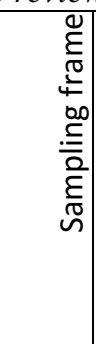 & 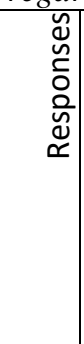 & 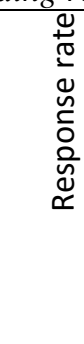 & 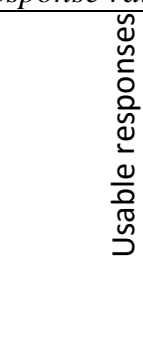 & $\frac{1}{0}$ & $\begin{array}{l}0 \\
0 \\
\mathbb{\alpha}\end{array}$ & 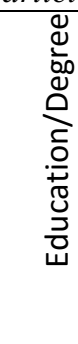 & Reference \\
\hline Enns & 2003 & 460 & & $16 \%$ & 75 & yes & yes & yes & $\begin{array}{l}\text { (Enns, Huff \& Golden , } \\
\text { 2003) }\end{array}$ \\
\hline Schmaltz & 2006 & 642 & 188 & $29 \%$ & 185 & no & no & no & $\begin{array}{l}\text { (Smaltz, Sambamurthy } \\
\& \text { Agarwal , 2006) }\end{array}$ \\
\hline $\mathrm{Li}$ & 2006 & & & & & no & yes & yes & (Li et al. , 2006) \\
\hline Chen & 2007 & 3700 & & & pre-test & no & yes & yes & (Chen \& Preston , 2007) \\
\hline Preston & 2008 & 3763 & 451 & $12 \%$ & & yes & no & yes & $\begin{array}{l}\text { (Preston, Chen \& } \\
\text { Leidner , 2008) }\end{array}$ \\
\hline Sobol & 2009 & & 123 & & & yes & yes & yes & (Sobol \& Klein , 2009) \\
\hline Cohen & 2010 & 421 & 114 & $27 \%$ & 111 & no & no & yes & $\begin{array}{l}\text { (COHEN \& DENNIS, } \\
\text { 2010) }\end{array}$ \\
\hline Chen & 2011 & & 218 & $23 \%$ & & no & no & no & (Chen \& Wu , 2011) \\
\hline $\mathrm{Li}$ & 2013 & 318 & 95 & $30 \%$ & & no & yes & yes & (Li \& Tan , 2013) \\
\hline Ding & 2014 & 2136 & 412 & $19 \%$ & & no & yes & yes & $\begin{array}{l}\text { (Ding, Li \& George , } \\
\text { 2014) }\end{array}$ \\
\hline Pare & 2020 & & & & 72 & no & no & no & $\begin{array}{l}\text { (Paré, Guillemette \& } \\
\text { Raymond, 2020) }\end{array}$ \\
\hline
\end{tabular}

${ }^{2}$ Own Paper „TWO DECADES OF CIO EFFECTIVENESS RESEARCH IN THE LIGHT OF THE PRINCIPAL-AGENT-THEORY: SUGGESTIONS FOR FUTURE RESEARCH" is accepted for presentation at the 13th international scientific conference „New Challenges in Economic an Business Development 2021 (May 2021), Riga, Latvia 
Source: Own results of literature review

The additional information in Table 1 like Sampling frame, Responses, Response rate and usable responses have been extracted from the research as they have been available.

For Business Research two Consulting companies, which frequently publish CIO Survey results, have been chosen: Harvey Nash in cooperation with KPMG and Deloite.

Their reports have been analysed for information about female CIOs.

\subsubsection{Database analysis}

Besides literature and internet-based information, a second method was used to generate alternative numbers for Germany. The company Bisnode maintains the former "Hoppenstedt Firmendatenbank". This database consists of information about German companies with financial numbers, addresses and names of $1^{\text {st }}$ and $2^{\text {nd }}$ level managers. For this research, a selection of companies with the criteria of $>125 \mathrm{Mio} € /$ a turnover was acquired (Table 2).

Table 2: Data of population and sample for database analysis

\begin{tabular}{|l|c|l|}
\hline $\begin{array}{l}\text { Population } \\
\text { (Companies >125 Mio. € Turnover per year in Germany) }\end{array}$ & \multicolumn{2}{|c|}{7471} \\
\hline Companies with available ClO Name & 3021 & $40.44 \%$ \\
\hline
\end{tabular}

Source: Own results of data analysis

The data was analysed with pivot tables to get valid information about Gender and doctoral degree in relation to industry and regional location.

\subsection{Results and Discussion}

The data collected through literature review are shown in Figure 1:

\subsubsection{Literature Review results on CIO Gender development}

The data collected through literature review are shown in Figure 1:

Figure 1: Share of female CIOs from different data sources period 1995-2020

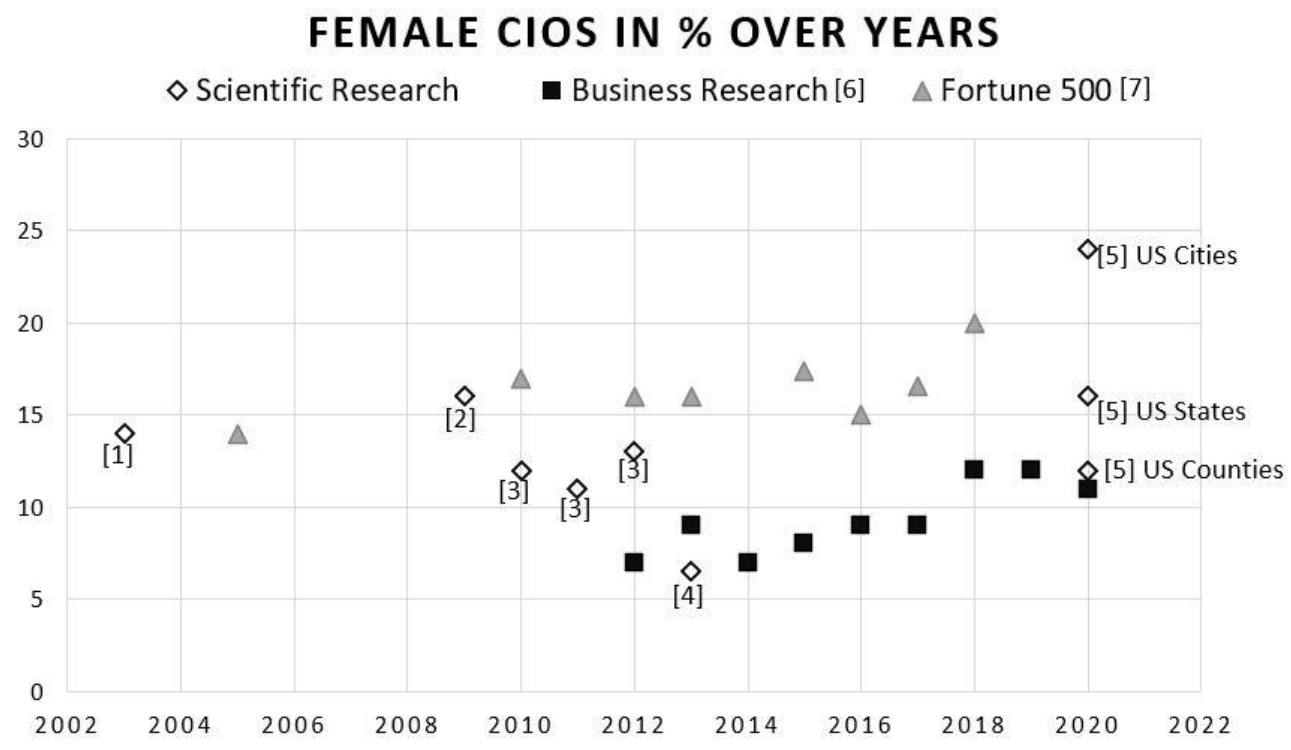


Data extracted from following sources: [number in chart] region/area, (published by):

[1] US, (Enns, Huff \& Golden , 2003); [2] US, (Sobol \& Klein , 2009); [3] US/academic, (van Ness , 2017); [4] Germany, (Termer , 2015); [5] US/State, (Martineau , 2020); [6] Global, 2012-2015: (Harvey Nash and KPMG International , 2015), 2016, 2017: (Harvey Nash / KPMG , 2017), 2018: (Harvey Nash / KPMG , 2018), 2019 : (Harvey Nash / KPMG , 2019), 2020: (White \& Bates , 2020); [7] US, (Statista , 2018)

Source: Own results of data analysis

As visible in the chart the share of female CIOs within one year can vary from study to study in a very wide range. The reason for this is the scope of these surveys (e.g. size of the company, region of the survey, industry/government, method of defining the population etc.) and very importantly the response behavior of the participants. As no central repository of CIOs is available the problem of wide variations within one year will most likely remain.

Therefore, all these surveys with limited statistical significance on the gender distribution might therefor not be the right choice to determine if an own survey-based dataset is representative in terms of gender distribution.

\subsubsection{Other approaches and sources to gain reliable data}

Due to the limitations of using survey based public available data or statistics for comparison with own datasets, a different approach would be obtaining viable data of CIOs from other organizations. One approach would be to ask interest groups, professional associations or online networks like cio.com for data. Yet, as all these organizations rely on voluntary membership associated with cost and/or journalistic research the data will be far from complete and reliable.

\subsubsection{Company databases as source for reliable data}

In the current data driven economy companies which collect, structure and sell company and consumer information are important for a variety of business functions within a company like market research and direct marketing. The quality of this data is usually appropriate, as these companies earn their money with the information.

The following approach relies on such a dataset which contains information about the company, address, turnover and most importantly $1^{\text {st }}$ and $2^{\text {nd }}$ line managers and their functions.

The dataset described in 2.1.2 contains information about CIO Name, CIO Gender, CIO Dr. Title and the kind of management position (top or middle management) and if available further responsibilities within the company.

This data was analyzed in two dimensions:

$1^{\text {st }}$ regarding the share of female CIOs in different industries (Table 4)

$2^{\text {nd }}$ regarding the share of female CIOs in different German federal states (Table 5). 
Table 4: Share of female CIOs in different industries.

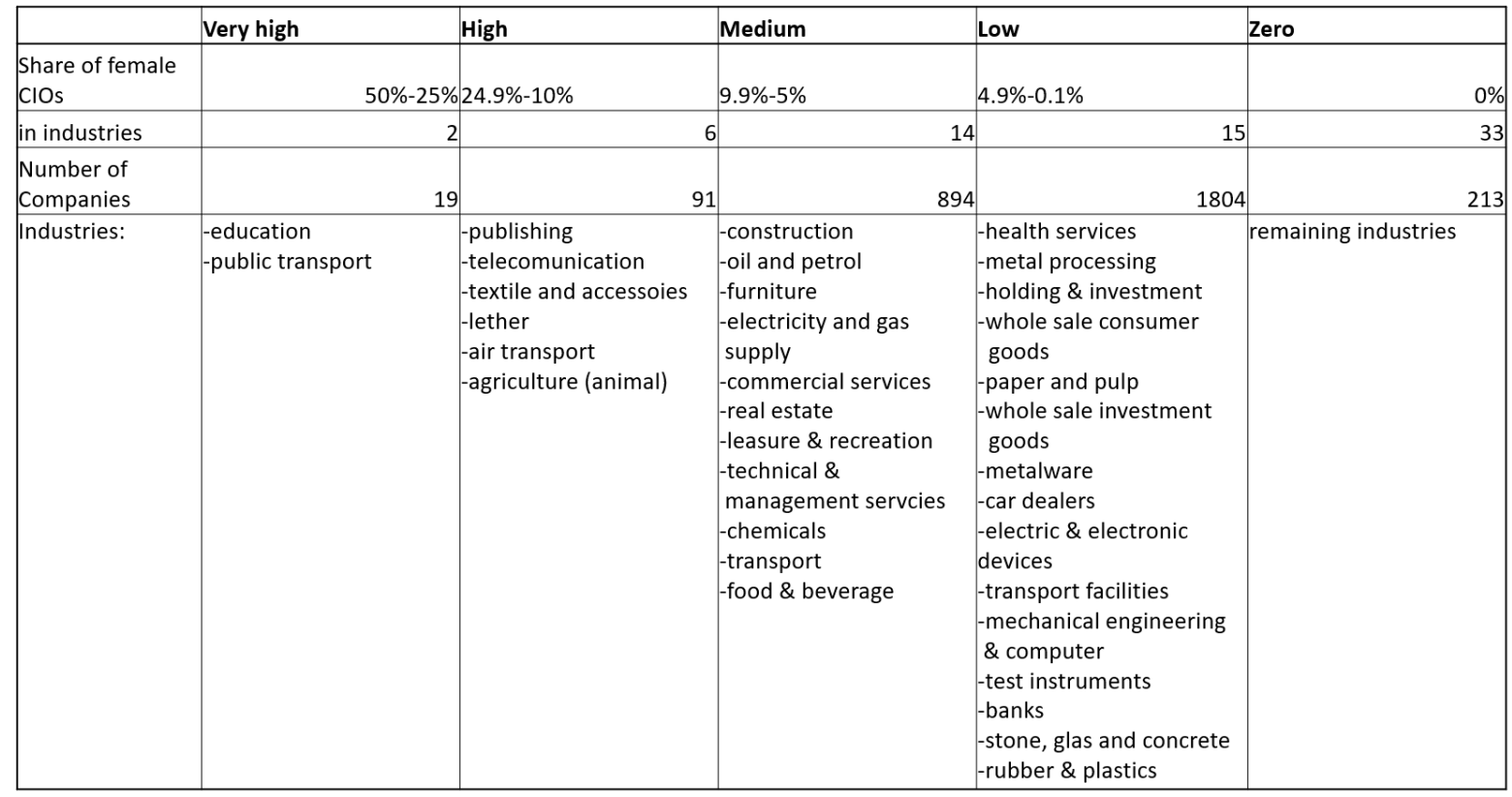

Source: Own calculations

Table 5: Share of female CIOs in German federal states

\begin{tabular}{|l|c|l|r|r|}
\hline & $\begin{array}{l}\text { Ranking: } \\
\text { Federal State } \\
\text { gross domestic } \\
\text { product }\end{array}$ & $\begin{array}{l}\text { Ranking: } \\
\text { number of companies } \\
\text { with }>125 \text { Mio.€ } \\
\text { turnover }\end{array}$ & $\begin{array}{l}\text { Companies } \\
\text { (N=) }\end{array}$ & $\begin{array}{l}\text { Female ClO } \\
\text { in \% }\end{array}$ \\
\hline Nordrhein-Westfahlen & 1 & 1 & 743 & 4.7 \\
\hline Bayern & 2 & 3 & 518 & 4.8 \\
\hline Baden-Würtemberg & 3 & 2 & 539 & 5.4 \\
\hline Niedersachsen & 4 & 5 & 260 & 3.8 \\
\hline Hessen & 5 & 4 & 312 & 3.8 \\
\hline Berlin & 6 & 9 & 77 & 5.2 \\
\hline Rheinland-Pfalz & 7 & 7 & 105 & 1.0 \\
\hline Sachsen & 8 & 10 & 57 & 10.5 \\
\hline Hamburg & 9 & 6 & 160 & 6.9 \\
\hline Schleswig-Holstein & 10 & 8 & 83 & 0.0 \\
\hline Brandenburg & 11 & 12 & 32 & 6.3 \\
\hline Thüringen & 12 & 15 & 18 & 11.1 \\
\hline Sachsen-Anhalt & 13 & 13 & 32 & 3.1 \\
\hline Mecklenburg-Vorpommern & 14 & 16 & 16 & 6.3 \\
\hline Saarland & 15 & 14 & 30 & 3.3 \\
\hline Bremen & 16 & 11 & 39 & 5.1 \\
\hline & & & 3021 & \\
\hline Sum & & & & \\
\hline
\end{tabular}

Source: Own calculations based on Hoppenstedt Firmendatenbank delivery from January 2021 (gross domestic ranking based on published data from 2019 Statista, 2019) 
The presented analysis of company databases is as diverse as the data extracted from scientific research and business surveys. The result of the share of female CIOs is highly dependent from the dimensions of analysis like regional location or industry branch affiliation of the companies. The finding that the highest share of female CIOs are - except for one case (Hamburg 6.9\%) - found in former eastern Germany (11.1\% Thüringen, 10.5\% Sachsen, 6.3\% Brandenburg and $6.3 \%$ Mecklenburg-Vorpommern). This shows that cultural differences resulting from former political systems might have long term impacts on gender demography.

\subsubsection{Comparison of survey and database results}

Volker Nissen and Frank Termer from the Technical University of Ilmenau showed 2013 in a internal, not published research Report (Termer \& Nissen , 2013) for the University, that the share of female CIOs is highly divers in different branches. The research based on the same address database from Bisnode and selection criteria was the same.

After further investigation of the results from Nissen and Termer (Nissen \& Termer, 2014) a major deviation was found which does not allow direct comparison of the results. The reason for this is that the Bisnode database classifies companies according to the wellestablished SIC Code ${ }^{3}$ (Standard Industrial Classification). Surveys from scholars (like the mentioned one from Nissen and Termer) often use other industry classification systematics which reflect industries which are important for a specific reason. One example for such a specialty is the "Automotive industry" category. Trying to match this category with the SIC Codes would require extracting certain companies from the Division D "Manufacturing" (SIC Codes 20-39). As the Bisnode database only uses the 2-digit code, a automated extraction of Automotive companies is not possible and therefore not part of this research.

Figure 2 shows the results from the analysis side-by-side for the distribution of companies in industries and the share of female CIOs in the industries in percent. I. is based on the survey results from Nissen and Termer and II. on the analysis of the 2021 Bisnode database extraction.

${ }^{3}$ The SIC Code (Standard Industrial Classification) was first established in 1937 and it is still in use by U.S. government departments and agencies. siccode.com Industry classification experts 
Figure 2: Comparison of results from survey $2013(n=216)$ and company database extract (n=3016) from 2021. Charts on companies per industry and share of female CIO in percent for both datasets.
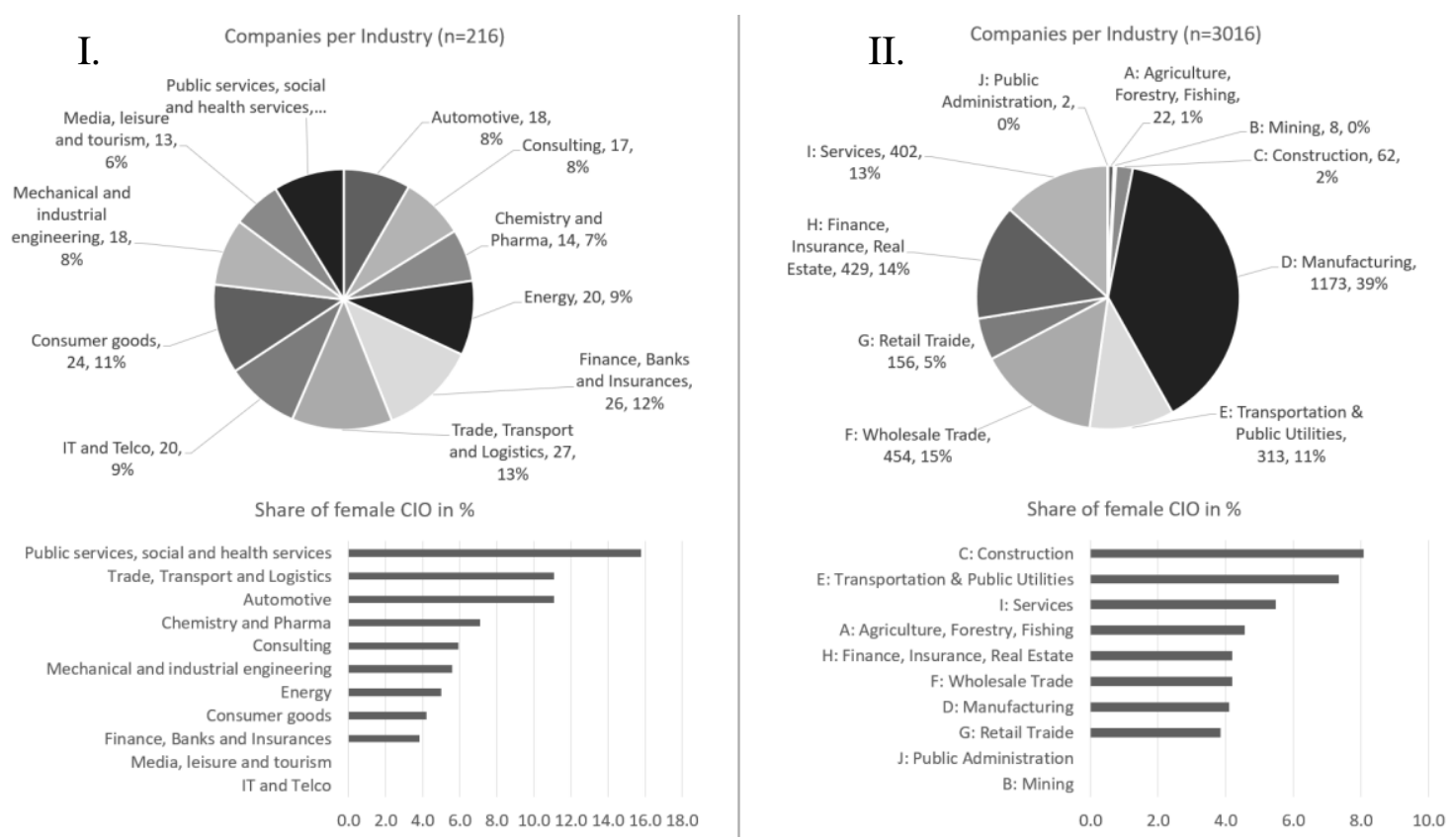

Source: Own calculations based on unpublished data from the Technical University of Ilmenau (Termer \& Nissen, 2013) and new analysis on an extract of the Bisnode Firmendatenbank (Companies with >125 Mio $€$ Turnover)

This methodological work shows that demographic data might vary depending on the dimensions of analysis, which are limited by the research object and the chosen population. It has a great influence on the comparability with other data sources. Great deviations can be observed within one year (see figure 1 depending on the regional scope or the selection of companies). The next factors are sample size and response rate. While the response rate compared with the overall population for survey data is sometimes quite small (overall population $(n=6602)$, used responses $(n=216)=3.27 \%$ in the case of Nissen/Termer (Nissen $\&$ Termer , 2014)) the "response rate" for the used company database is, with $40.44 \%$, quite high as all complete datasets could be used for the calculations - See Table 2.

For this reason, researchers, which intend to test if their survey data is a representative sample in terms of a specific demographic variable, should thoroughly think and decide about the public available data which they want to compare their own data with to ensure statistic valid conclusions.

\section{References}

Chan, Y.E, Sabherwal, R. \& Thatcher, J.B , 2006. Antecedents and outcomes of strategic IS alignment. An empirical investigation, IEEE Transactions on Engineering Management, vol. 53, no. 1, pp. 27-47. 
Chen, D. \& Preston, D. , 2007. Understanding CIO Role Effectiveness. The Antecedents and Consequents. 2007 40th Annual Hawaii International Conference on System Sciences (HICSS'07), IEEE, 237a-237a.

Chen, Y.-C. \& Wu, J.-H. , 2011. IT management capability and its impact on the performance of a CIO, Information \& Management, vol. 48, 4-5, pp. 145-156.

COHEN, J. \& DENNIS, C.M , 2010. Chief information officers:. an empirical study of competence, organisational positioning and implications for performance, South African Journal of Economic and Management Sciences,, vol. 13, no. 2, pp. 203-221.

Ding, F., Li, D. \& George, J.F , 2014. Investigating the effects of IS strategic leadership on organizational benefits from the perspective of CIO strategic roles, Information \& Management, vol. 51, no. 7, pp. 865-879.

Durst, M. , 2007, Wertorientiertes Management von IT-Architekturen, Teubner.

Enns, H.G, Huff, S.L \& Golden, B.R , 2003. CIO influence behaviors. The impact of technical background, Information \& Management, vol. 40, no. 5, pp. 467-485.

Fitzsimmons, T.W, Callan, V.J \& Paulsen, N. , 2014. Gender disparity in the C-suite. Do male and female CEOs differ in how they reached the top?, The Leadership Quarterly, vol. 25, no. 2, pp. 245-266.

Harvey Nash / KPMG, 2017. CIO Survey 2017 - Infographic: Key findings. Available from: https://advisory.kpmg.us/articles/2017/cio-survey-harvey-nash-2017.html [04 February 2021].

Harvey Nash / KPMG, 2018. CIO Survey 2018 Infographic. Available from: https://advisory.kpmg.us/articles/2018/cio-survey-2018-executive-summary.html [04 February 2021].

Harvey Nash / KPMG, 2019. CIO Survey 2019 - Infographic . Available from: https://home.kpmg/content/dam/kpmg/xx/pdf/2019/06/harvey-nash-cio-surveyinfographic.pdf [04 February 2021].

Harvey Nash and KPMG International, 2015. CIO Survey 2015 Full Report. Available from: https://assets.kpmg/content/kpmg/2016/harvey-nash-cio-survey-2015.pdf [04 February 2021].

Hodgkinson, S.L , 1992. IT structures for the 1990s: organisation of IT functions in large companies.

A survey., Information \& Management, vol. 22, no. 3, 161-175.

Li, Y. \& Tan, C.-H. , 2013. Matching business strategy and CIO characteristics. The impact on organizational performance, Journal of Business Research, vol. 66, no. 2, pp. 248259.

Li, Y., Tan, C.-H., Teo, H.-H. \& Tan, B.C.Y. , 2006. Innovative usage of information technology in Singapore organizations. Do CIO characteristics make a difference?, IEEE Transactions on Engineering Management, vol. 53, no. 2, pp. 177-190.

Marrone, M. \& Kolbe, L.M , 2011. Impact of IT Service Management Frameworks on the IT Organization, Business \& Information Systems Engineering, vol. 3, no. 1, pp. 5-18. 
Martineau, P , 2020, Gov Tech's Gender Gap: Getting More Women in Government IT. Available from: https://www.govtech.com/people/Gov-Techs-Gender-Gap-GettingMore-Women-in-Government-IT.html [08 February 2021].

Moher, D., Shamseer, L., Clarke, M., Ghersi, D., Liberati, A., Petticrew, M., Shekelle, P. \& Stewart, L.A , 2015. Preferred reporting items for systematic review and meta-analysis protocols (PRISMA-P) 2015 statement, Systematic reviews, vol. 4, p. 1.

Nissen, V. \& Termer, F., 2013, Eine Bestandsaufnahme zum IT-Management in Deutschland. Ergebnisse einer Befragung unter CIOs, Arbeitsbericht Nr. 2013-03, August 2013, Technische Universität Ilmenau, Fakultät für Wirtschaftswissenschaften, Institut für Wirtschaftsinformatik.

Nissen, V. \& Termer, F. , 2014. Business - IT-Alignment - Ergebnisse einer Befragung von IT-Führungskräften in Deutschland, HMD Praxis der Wirtschaftsinformatik, vol. 51, no. 5, pp. 549-560.

Paré, G., Guillemette, M.G \& Raymond, L. , 2020. IT centrality, IT management model, and contribution of the IT function to organizational performance. A study in Canadian hospitals, Information \& Management, vol. 57, no. 3, p. 103198.

Peppard, J. , 2010. Unlocking the Performance of the Chief Information Officer (CIO), California Management Review, vol. 52, no. 4, pp. 73-99.

Prabhakar, K., Lamar, K., Shaikh, A. \& Brown, C. , 2018, Smashing IT'sglass ceiling. Perspectives from leadingwomen CIOs, Deloite.

Preston, D.S, Chen, D. \& Leidner, D.E , 2008. Examining the Antecedents and Consequences of CIO Strategic Decision-Making Authority. An Empirical Study*, Decision Sciences, vol. 39, no. 4, pp. 605-642.

Schweda, C.M \& Schmidt, W. , 2014. Leichtgewichtiges, unternehmensspezifisches ITManagement, HMD - Praxis der Wirtschaftsinformatik, vol. 51, no. 5, pp. 606-615.

siccode.com Industry classification experts, History of SIC Codes. Available from: https://siccode.com/page/history-of-sic-codes [08 February 2021].

Smaltz, D.H, Sambamurthy, V. \& Agarwal, R., 2006. The antecedents of CIO role effectiveness in Organizations. An empirical study in the healthcare sector, IEEE Transactions on Engineering Management, vol. 53, no. 2, pp. 207-222.

Sobol, M.G \& Klein, G. , 2009. Relation of CIO background, IT infrastructure, and economic performance, Information \& Management, vol. 46, no. 5, pp. 271-278.

Statista , 2018, Percentage of female Chief Information Officers in Fortune 500 companies from 1995 to 2018. Available from: https://www.statista.com/statistics/311958/fortune500-female-cio/ [04 February 2021].

Statista, 2019, Bruttoinlandsprodukt (BIP) in Deutschland nach Bundesländern im Jahr 2019. Available from:

https://de.statista.com/statistik/daten/studie/36889/umfrage/bruttoinlandsprodukt-nachbundeslaendern/ [04 February 2021]. 
Synnott, W.R \& Gruber, W.H , 1981, Information resource management. Opportunities and strategies for the 1980s, Wiley, New York.

Tallon, P.P , 2014. A Process-Oriented Perspective on the Alignment of Information Technology and Business Strategy, Journal of Management Information Systems, vol. 24, no. 3, pp. 227-268 [02 March 2020].

Termer, F. , 2015, Determinanten der IT-Agilität. Theoretische Konzeption, empirische Analyse und Implikationen, Springer Gabler [26 January 2021].

van Ness, S. , 2017, The Role of Gender in Hiring Officials' Perceptions of Chief Information Officer Candidates. Dissertation, Walden University, Minneapolis, Minnesota [21 January 2021].

White, B. \& Bates, S. , 2020, Harvey Nash / KPMG CIO Survey 2020: Everything changed. Or did it? Available from: https://home.kpmg/xx/en/home/insights/2020/09/harveynash-kpmg-cio-survey-2020-everything-changed-or-did-it.html [21 January 2021]. 